\title{
Polskie toksyczne opcje walutowe
}

\section{Streszczenie}

Opcje walutowe (ang. currency options) należa do pochodnych instrumentów finansowych (derywatów). W przypadku opcji walutowych instrumentem bazowym jest waluta obca. Cena wykonania, po której właściciel opcji może, ale nie musi (stąd opcja, czyli możliwość) kupić lub sprzedać instrument pierwotny od wystawcy opcji, wyrażona jest $w$ kursie waluty. Toksyczne opcje walutowe definiuje się $w$ tym opracowaniu $w$ oparciu o opozycję wobec natury umowy opcyjnej, co znajduje uzasadnienie normatywne na gruncie art. 353-1 k.c., gdzie występuje klauzula generalna właściwości (natura) stosunku, jako samoistna przesłanka reglamentujaca swobodę zawierania umów. Artykut omawia opcje toksyczne w Polsce w oparciu o zasady i terminologie nauk prawnych.

\section{Wprowadzenie}

Istotą (naturą) umowy opcyjnej, odróżniającą ją od innych zobowiązań jest asymetryczny rozkład ryzyka gospodarczego, którym zostają obarczone strony. Kupujący opcję kupna (ang. call option) po zapłaceniu wystawcy (zbywcy) opcji premii opcyjnej (ang. ption premium - opłata za opcję) staje się uprawnionym do kupienia w przyszłości od wystawcy opcji instrumentu pierwotnego, np. waluty, po z góry określonej cenie. Wystawca, (jako podmiot zobowiązany z opcji) jest zobligowany uprawnienie to zrealizować, czyli jest zobowiązany sprzedać walutę. Jeśli cena instrumentu pierwotnego zmaleje (kurs EUR/PLN), uprawniony nie wykona opcji, gdyż musiałby kupować od wystawcy instrument pierwotny po cenie wykonania wyższej od ceny bieżącej. Premia opcyjna będzie jego stratą i jednocześnie dochodem wystawcy. Taką opcję nabył grecki filozof Tales (ży-

\footnotetext{
* Dr, adiunkt na Wydziale Prawa Wyższej Szkoły Finansów i Zarządzania w Warszawie.
} 
jący na przełomie VII i VI wieku przed narodzinami Chrystusa), a opisał to Arystoteles (w IV wieku przed narodzinami Chrystusa). Takie opcje nabywały też od polskich eksporterów banki. Opcje te - powiedzmy: polskie opcje walutowe - stały się problemem na przełomie lat 2008-2009.

Istnieje też opcja sprzedaży (ang. put option), która działa odwrotnie. Eksporterzy ponoszą koszty w walucie rodzimej. Dochody osiagają w walucie obcej. Taka sytuacja w naturalny sposób otwiera eksporterowi długą pozycję w walucie obcej i czyni go wrażliwym na spadek kursu walutowego. Eksporter może zdecydować się wtedy na operację zabezpieczającą przed ryzykiem (hedgingową) polegającą na cesji ryzyka dokonywanej poprzez umowę o derywaty (instrumenty pochodne). Eksporter jako nabywca opcji sprzedaży zabezpiecza się przed spadkiem (ma zagwarantowaną cenę sprzedaży), czyli przewiduje spadek ceny instrumentu bazowego. Jeśli eksporter nie jest w stanie przewidzieć przyszłych zmian ceny instrumentu bazowego (np. kursu euro), powinien wybrać pozycję przeciwną do zajmowanej w sposób naturalny, tzn. powinien zdecydować się na krotką pozycję w kontraktach forward. Jednakże, nie pozwoli to eksporterowi czerpać dodatkowych dochodów, gdy kurs waluty zmieni się dla niego korzystnie, tzn. gdy wzrośnie.

\section{Naturalna asymetria ryzyka opcyjnego}

W przypadku polskich opcji walutowych, bank wystawiając eksporterowi opcję $p u t$, tak jak każdy wystawca opcji, brał na siebie ryzyko walutowe w zamian za premię opcyjna. Słowem, bank kupował cudze ryzyko. Spadek kursu euro oznaczał dochód eksportera i zarazem stratę banku. Przedsiębiorstwo nabywając opcję put (sprzedaży) zabezpieczało się przed spadkiem kursu walutowego. Czyniło tak w zamian za zapłacenie bankowi stosunkowo niewielkiej premii opcyjnej, której mogło uniknąć, jeśli zgodziło się z kolei wystawić bankowi opcję call (kupna). Bank jako nabywca opcji kupna (pozycja long call) zabezpieczał się przed wzrostem ceny instrumentu pierwotnego (miał zagwarantowany kurs euro, po którym kupuje walutę od eksportera przy wzroście kursu bieżącego), czyli przewidywał, że cena bieżąca (kurs bieżący) wzrośnie. Tak powstały strategie „,zerokosztowe".

Ponieważ po zapłaceniu premii opcyjnej zobowiązaną jest tylko jedna strona (wystawca opcji), w związku z umowami opcyjnymi występują następujące asymetrie naturalne rozkładu ryzyka (por. rys. 1):

- asymetria strukturalna,

- asymetria rynkowa (funkcjonalna).

Naturalna asymetria strukturalna wynika $\mathrm{z}$ istoty opcji (opcja jako prawo). Polega na tym, że w momencie zawierania umowy opcyjnej z góry można określić maksymalną stratę nabywcy opcji (strata posiadacza opcji put, występuje przy wzroście ceny bieżącej instrumentu pierwotnego, np. przy wzroście kursu EUR/PLN; jest to pozycja polskich eksporterów; strata posiadacza opcji call występuje przy odwrotnej zmianie ceny instrumentu pierwotnego, tj. przy spadku kursu EUR/PLN; jest to pozycja banków). Strata posiadacza opcji jest jednocześnie dochodem wystawcy. Jest nią premia opcyjna płacona wystawcy opcji. Natomiast niewiadomą jest strata wystawcy opcji (w opcji call i po- 
Rys. 1. Rodzaje naturalnej asymetrii ryzyka opcyjnego

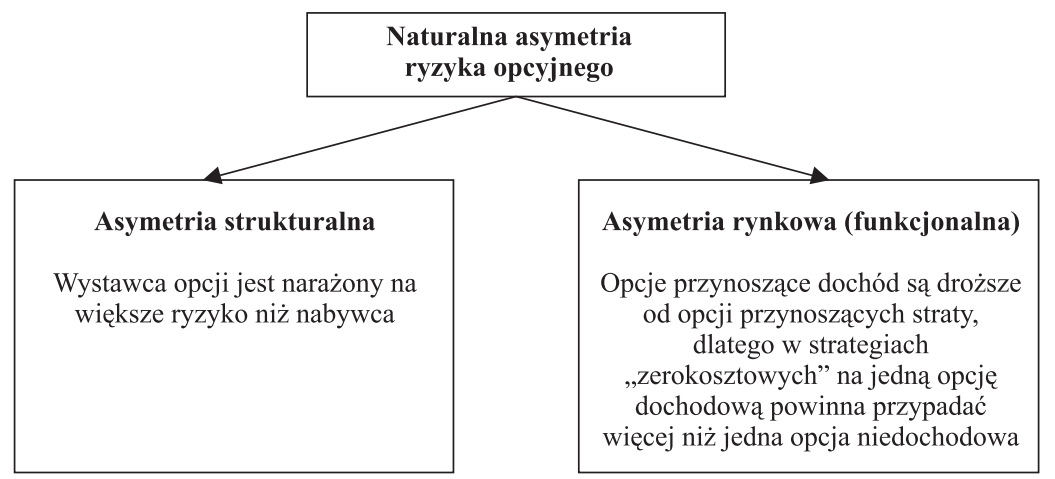

Źródło: Opracowanie własne.

zycji polskich eksporterów, strata następuje przy wzroście kursu EUR/PLN; w opcja put i pozycji banków, strata następuje przy spadku kursu EUR/PLN), która będzie zarazem dochodem nabywcy - zależy jedynie od zmiany ceny bieżącej instrumentu pierwotnego.

$\mathrm{Z}$ kolei naturalna asymetria rynkowa (funkcjonalna) opcji jest konsekwencją rynkową naturalnej asymetrii strukturalnej, tzn. daje o sobie znać w związku z rynkową realizacją umowy opcyjnej. Zależy jedynie od aktualnych trendów rynkowych. Jeśli opłaca się wykonać opcję, mówimy, że jest ona w cenie (ang. in-the-money - ITM). Ma to miejsce, gdy cena wykonania opcji call jest niższa niż bieżąca cena instrumentu bazowego, zaś cena wykonania opcji put jest wyższa od ceny instrumentu pierwotnego. Jeżeli kurs EUR/PLN ciagle maleje, oznacza to, że również cena wykonania opcji put jest wyższa od ceny instrumentu bazowego. Jest to więc opcja put ITM, która ze względu na mającą miejsce na rynku opcyjnym grę podaży z popytem, cieszy się dużym powodzeniem (rośnie popyt). Rynek opcyjny reaguje w ten sposób, że rośnie cena opcji put ITM (premia opcyjna), tak jak każdej opcji ITM, którą trzeba zapłacić wystawcy tej opcji przy jej nabyciu. Opcja call jest wtedy (deprecjacja euro) opcją OTM (ang. out-of-the-money), czyli nie opłaca się jej wykonywać, tzn. właścicielowi opcji call, przy malejącej cenie instrumentu pierwotnego bardziej opłaca się stracić premię opcyjną niż kupować od wystawcy instrument pierwotny (walutę, tutaj euro) po cenie wyższej od rynkowej. Na opcję call OTM (ma to miejsce przy spadku ceny instrumentu pierwotnego) nie ma więc zapotrzebowania i w konsekwencji jej cena (premia opcyjna) jest niska w stosunku do opcji put ITM. Dlatego polscy eksporterzy przy strategiach ,zerokosztowych” - zawieranych w połowie 2008 r. (dłużej utrzymująca się deprecjacja euro) - byli w sposób naturalny (wynikający z sytuacji rynkowej) jednocześnie nabywcą i wystawcą opcji, nie tylko na tę samą kwotę euro (instrument pierwotny, którego cena bieżąca wyrażana jest w kursie EUR/PLN). Na podstawie opcji call zobowiązywali się dostarczyć bankowi euro w kwocie kilkakrotnie większej (nominał zobowiązań eksportera z opcji) niż bank miał obowiązek kupić na podstawie opcji put (nominał praw eksportera z opcji). W praktyce oznaczało to wystawienie przez przedsiębiorstwa eksportujące opcji na wielokrotność zabezpieczanego nominału. 
Słowem, z równowagi rynkowej podaż/popyt wynika, że na jedną opcję put ITM, wystawianą przez bank, musiała przypadać więcej niż jedna opcja call OTM, wystawiana przez eksportera. Co do zasady, opcje OTM zawsze są bowiem tańsze niż opcje ITM. Stąd naturalna asymetria funkcjonalna ryzyka opcyjnego.

Jeśli przedsiębiorstwo prognozuje znaczny spadek ceny bieżącej, najlepiej jest zająć pozycję długą na opcji put (tak czynili polscy eksporterzy, gdy do połowy 2008 r. kurs euro malał), ale ze względu na parcie popytowe, opcje te, jako opcje ITM, zwykle są stosunkowo drogie (w stosunku do opcji call OTM). Konsekwencje naturalnej asymetrii ryzyka opcyjnego przedstawiają się następująco:

- kupujący opcje (ang. long position) zawsze mniej ryzykuje niż jego kontrahent,

- biorącym na siebie ryzyko - tzn. spekulantem - zawsze jest wystawca opcji, czyli zbywca opcji (ang. short position),

- aczkolwiek z efektu dodatniej dźwigni finansowej (ang. leverage) korzystać może też kupujący opcję, a więc również realizuje cel spekulacyjny,

- kupujący opcję stosuje hedging oparty na wykorzystaniu przewidywań formułowanych w oparciu o wiedzę, co do zmian cen dokonujących się w określonym czasie, a w ten sposób w inżynierii finansów definiuje się spekulację. Kupujący czyni tak w celach bezpośrednio zarobkowych (podejście nieawersyjne do ryzyka - podejmowanie ryzyka korzyści), a nie tylko w celu przeciwdziałania stratom, czyli pośrednio zarobkowych (podejście awersyjne do ryzyka, tj. branie pod uwagę tylko możliwości wystąpienia ryzyka strat),

- nabywca opcji ryzykuje (chociaż stosunkowo niewiele, tzn. tylko premią opcyjna), czyli nie podporządkowuje się zasadzie (,zarobić skromnie, by dużo nie stracić” albo ,niewielki zysk w zamian za zmniejszenie ryzyka”). Korzysta z elementu spekulacyjnego na zasadzie ,,ponadprzeciętnie zaryzykować, by zarobić ponadprzeciętnie", ale realizuje tak zidentyfikowaną zasadę na niższym poziomie niż spekulant (kupujący ryzyko w zamian za premię opcyjna), który z kolei kieruje się zasadą: ,„ponadprzeciętnie zaryzykować, by zarobić ponadprzeciętnie”.

\section{Nienaturalna (toksyczna) asymetria ryzyka opcyjnego}

W opozycji do scharakteryzowanej w punkcie 1 artykułu naturalnej asymetrii ryzyka opcyjnego, teoretycznie wyodrębnić możemy trojakiego rodzaju opcyjną asymetrię toksyczną, czyli nienaturalną - oznaczającą sprzeczność z iuris cogentis, tj.: toksyczność informacyjną, umowną oraz rynkową (funkcjonalna). Rodzaje toksycznej asymetrii ryzyka opcyjnego podano na rys. 2.

Toksyczność informacyjna występuje, gdy przy zawieraniu umowy opcyjnej bank nie udziela przedsiębiorstwu informacji o ryzyku opcyjnym. Toksyczność (nienaturalność) informacyjna oznacza poczwórną sprzeczność z prawem (bezprawność):

- sprzeczność z systemem MiFID - w szczególności przepisy art. 19 dyrektywy 2004/39/WE w zw. z np. art. 94 ust. 1 pkt 1 in fine obecnie obowiązującej ustawy z dnia 29 lipca 2005 r. o obrocie instrumentami finansowymi (obliguje banki do należytej staranności, ochrony klienta oraz bezpiecznego i sprawnego zawierania 
Rys. 2. Rodzaje toksycznej asymetrii ryzyka opcyjnego

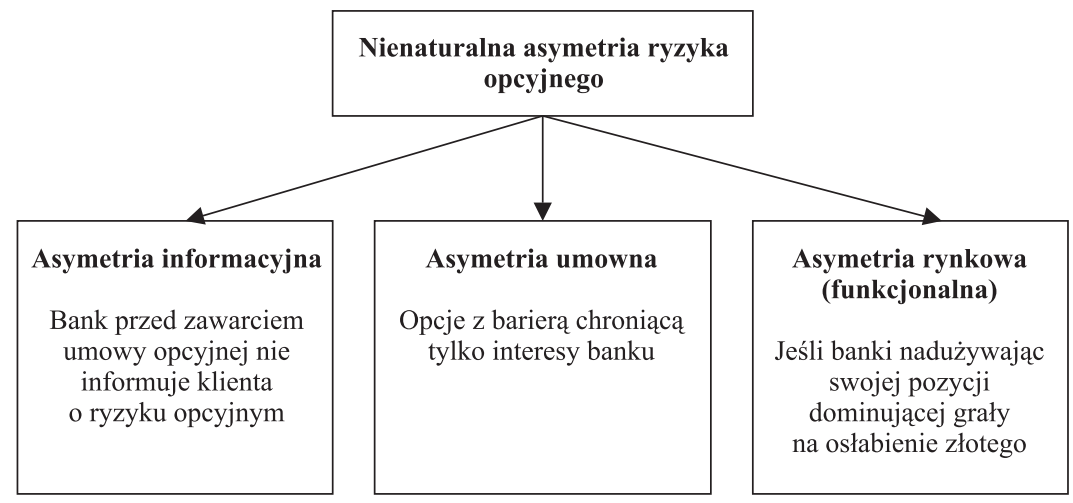

Źródło: Opracowanie własne.

i rozliczania transakcji, a także przejrzystości i bezpieczeństwa obrotu). Dodajmy, że bank jako instytucję zaufania publicznego, zgodnie z orzecznictwem Sądu Najwyższego i Trybunału Konstytucyjnego, obowiązuje podwyższony standard staranności (powiedzmy: szczególna staranność). Dyrektywa 2004/39/WE, tak jak uszczegółowiająca ją dyrektywa 2006/73/WE, nie została dotychczas implementowana do systemu polskiego, chociaż termin minął w dniu 1 listopada 2007 r. (art. 70 dyrektywy 2004/39/WE). Jednak ze względu na zasadę supremacji acquis communautaire (vide m.in. wyrok ETS z dnia 5 lutego 1963 r. w sprawie 26/62 oraz wyrok ETS z dnia 15 lipca 1964 r. w sprawie 6/64) i zasadę skutku pośredniego nieimplementowanej dyrektywy w relacjach horyzontalnych (m.in. wyrok ETS z dnia 13 listopada 1990 r. w sprawie C-106/89 oraz wyrok z dnia 14 lipca 1994 r. w sprawie C-91/92), system MiFID - jako przepisy na tyle precyzyjne i szczegółowe, że można z nich wydobyć zakres obowiązku informacyjnego banku wobec klienta nadaje się do stosowania przy wykładni prawa krajowego. Słowem, sąd krajowy ma obowiązek interpretować prawo krajowe z uwzględnieniem nawet nieimplementowanej dyrektywy, jak zaakcentowano w powyższych orzeczeniach luksemburskich, na zasadzie as far as possible (a nie wg zasady in so far as it is given discretion to do so under national law). Oto zgodnie z art. 19 ust. 5 akapit trzeci dyrektywy 2004/39/WE: W przypadkach, gdy klient lub potencjalny klient podejmuje decyzje o nieprzekazywaniu informacji określonych na podstawie akapitu pierwszego lub jeżeli przedstawia niewystarczajace informacje dotyczqce jego wiedzy $i$ doświadczenia, przedsiębiorstwo inwestycyjne ostrzega klienta lub potencjalnego klienta, że taka decyzja uniemożliwia przedsiębiorstwu ustalenie, czy przewidziana ustuga lub produkt sq dla niego odpowiednie. Ostrzeżenie to należy przekazywać $w$ ujednoliconym formacie. Jak z tego wynika, nie wystarczy, że w umowie opcyjnej klient oświadczy, iż: (1) jest świadom ryzyka związanego z zawieraniem transakcji opcyjnych, albo (2) działa wyłącznie w oparciu o własne rozeznanie oraz dokonane analizy, a także rady swoich doradców odnośnie zasadności i celowości wy- 
boru i zawarcia transakcji opcyjnej, bądź (3) przyjmuje do wiadomości, że bank nie świadczy doradztwa $\mathrm{w}$ związku z transakcjami opcyjnymi ani nie udziela jakichkolwiek porad inwestycyjnych lub rekomendacji co do tych transakcji; nie wystarczy nawet (4) oświadczenie, że klient został wyczerpująco poinformowany przez bank o ryzyku opcyjnym. Dodatkowo z akapitu drugiego i trzeciego ust. 5 art. 19 - wynika, że bank jest zobligowany udowodnić, że przetestował klienta odnośnie ryzyka opcyjnego, bądź że klient nie chciał poddać się takiemu testowi;

- sprzeczność z ustalonymi zwyczajami - art. 56 k.c. (ustawa, zasady wspólżycia spotecznego i utrwalone zwyczaje jako czynniki kształtujące czynność prawną) w zw. $\mathrm{z}$ „Zasadami dobrej praktyki bankowej” (dokument opublikowany przez Związek Banków Polskich), w szczególności Rozdział II pkt. 4 (Bank powinien informować klienta o rodzajach $i$ warunkach świadczonych usług, wyjaśniając różnice między poszczególnymi oferowanymi ustugami ze wskazaniem korzyści, które dana ustuga gwarantuje oraz zwiqzanych $z$ danq ustuga ryzykach);

- sprzeczność z dobrymi obyczajami - art. 72 § 2 k.c. (culpa in contrahendo). Bank, jako instytucję zaufania publicznego, obowiązuje nie tylko podwyższony standard staranności, lecz także podwyższony standard moralności zawarty w klauzuli generalnej dobrych obyczajów. Stąd można wyprowadzić mający konotację moralną obowiązek prawny banku informowania o ryzyku opcyjnym klientów już na etapie przedkontraktowym, co jest sankcjonowane jako culpa in contrahendo. Później, tj. po zawarciu umowy, obowiązek ten będzie brany pod uwagę przy interpretacji klauzuli generalnej zasad współżycia społecznego (np. z art. 56 k.c., art. 58 § 2 k.c. i art. 353-1 k.c.), która zawiera normy moralne. W myśl rzymskiej zasady: Pacta quae contra leges constitutionesque vel contra bonos mores fiunt, nullam vim habere (umowy, które są sprzeczne z prawem, konstytucjami cesarskimi lub dobrymi obyczajami, nie mają mocy prawnej);

- sprzeczność z art. 45 ust. 1 Konstytucji (prawo do sądu) w zw. z art. 96 ust. 1 ustawy z dnia 29 sierpnia 1997 r. - Prawo bankowe (bankowy tytuł egzekucyjny). Konstytucyjna gwarancja określana jako prawo do sądu obejmuje nie tylko prawo do rozpoznania sprawy w postępowaniu sądowym, ale także prawo do odpowiedniego ukształtowania procedury, która zapewnia rzetelne i sprawiedliwe rozstrzygnięcie. Bankowy tytuł egzekucyjny nie może być uznany za instytucję naruszającą tak pojmowane prawo do sądu ze względu na samą możliwość dopuszczenia do postępowania egzekucyjnego bez uprzedniego rozstrzygnięcia sądowego co do meritum sprawy - pod warunkiem, że uciążliwości dłużnika, polegającej na możliwości wszczęcia postępowania przeciwegzekucyjnego, towarzyszy po stronie banku obowiązek informacyjny tak daleko idący, że co do rezultatu pokrywający się z obowiązkiem informacyjnym wynikającym z MiFID albo z ustalonych zwyczajów określanych jako „Zasady dobrej praktyki bankowej” (vide: wyrok Trybunału Konstytucyjnego z dnia 26 stycznia 2005 r. P 10/04).

Toksyczność informacyjna, w każdej z czterech powyżej scharakteryzowanych postaci, może być sankcjonowana przez przepisy statuujące przestępstwo oszustwa. Niezrealizowanie obowiązku informacyjnego odnośnie ryzyka opcyjnego przez bank wobec eksportera wchodzącego z bankiem w transakcje opcyjne, należy rozpatrywać w kontek- 
ście znamion oszustwa (przy ewentualnej odpowiedzialności indywidualnej funkcjonariuszy banku). Bank może w ten sposób (poprzez swoje zaniechanie odnośnie obowiązku informowania o ryzyku, co oznacza zaniechanie poinformowania o faktycznym stanie rzeczy) wyzyskiwać błą eksportera odnośnie tego, czy w danej strategii opcyjnej dominuje element hedgingowy czy spekulacyjny. Miałoby miejsce swoiste obchodzenie reguły „gry” (w znaczeniu obowiązków), naruszające założoną przez te reguły równość szans jej uczestników.

Jeśli jednak bank zrealizuje swój obowiązek informacyjny i do kontraktu opcyjnego dojdzie, a klient (tutaj eksporter) w wyniku tego kontraktu odnotuje szkodę, wówczas już od czasów antycznych - stosuje się (tutaj wobec banku) maksymę: ,executio iuris non habet iniuriam" (wykonywanie prawa nie jest bezprawiem).

Toksyczność umowna z kolei to zmodyfikowany umownie, na niekorzyść polskich eksporterów, rozkład ryzyka, np. w opcjach z barierą. Bariera polega np. na tym, że opcja wygasa po określonej liczbie wpłat z tytułu wykonywania przez bank opcji put (przy deprecjacji euro) albo po uzyskaniu przez eksportera z góry określonej liczby wypłat z tytułu rozliczeń dokonanych przez bank (też przy deprecjacji euro). Natomiast na wypadek, gdy przedsiębiorstwo ponosiło straty z wystawienia opcji call (przy aprecjacji euro), w umowie nie przewidziano analogicznego warunku wyłączającego opcję. Inaczej mówiąc, umowa nierównomiernie rozkładała uprawnienia i obowiązki stron odnośnie ryzyka opcyjnego. Dokonując subsumcji zauważymy, że nawet w umowach obustronnie profesjonalnych, gdzie obowiązuje zasada podwyższonej dbałości o swoje interesy (dekodowana z należytej staranności), w przypadku barrier options można mówić o umownej toksyczności bezprawnej, jeśli jednostronnie działająca bariera powoduje, że w umowie opcyjnej dochodzi do nierównomiernego rozkładu uprawnień i obowiązków, czyli do nie uwzględniania interesów jednej strony w określonym zakresie. Podstawą prawną są klauzule generalne właściwość (natura) stosunku i zasady współżycia społecznego w rozumieniu art. 353-1 k.c.; odnośnie zasad współżycia społecznego także art. 58 § 2 k.c. Ze względu na zasadę równości stron stosunku obligacyjnego - zakodowaną w tych dwóch klauzulach generalnych - równość gwarantuje się także w ten sposób, że chroniąc stronę słabszą (konsumenta) przed mocniejszą (bank-profesjonalistą), zapewnia się w ostateczności równość stron. Słowem, równych traktujemy równo, nierównych - nierówno. Zasada ta powstaje w wyniku połączenia zasad sprawiedliwości społecznej (art. 2 Konstytucji) i równości wobec prawa (art. 32 ust. 1 zd. pierwsze Konstytucji). Na tym polega arystotelesowska koncepcja „,sprawiedliwości rozdzielającej” (czyli sprawiedliwości dystrybutywnej, proporcjonalnej), zakładająca jednakowe traktowanie (dzielenie dóbr i rozkład ciężarów) ludzi (podmiotów prawa) tej samej kategorii, tj. znajdujących się w podobnej sytuacji prawnej (Etyka nikomachejska, 1131-1131b). Odnosimy to niekiedy również do umów obustronnie profesjonalnych. W umowach bankowych judykatura traktuje klienta banku jako stronę słabsza, nawet jeśli jest nią podmiot gospodarczy. W konsekwencji umowy w obrocie profesjonalnym z nierównomiernym rozkładem uprawnień i obowiązków uznaje się w orzecznictwie Sądu Najwyższego za sprzeczne z iuris cogentis. Jest to podejście restrykcyjne. Czyni się tak ze względu na charakter banku, jako instytucji zaufania publicznego, od której należy wymagać szczególnej staranności. Ponadto z zasady słuszności wynika, że nawet przy podejściu liberalnym, wyrażanym w doktrynie - 
uznającym za dopuszczalne postanowienie umowne przewidujące, iż świadczenie zostanie określone przez jedną ze stron stosunku prawnego - strona uprawniona powinna określać świadczenie według słusznego uznania, a więc w sposób nie dowolny, lecz przeciwnie, w sposób uwzględniający całokształt okoliczności, w tym również interes drugiej strony. W tym sensie każda umowa, której realizacja polega na nieuwzględnieniu interesów jednej ze stron w określonym zakresie - jest bezprawna. Dotyczy to nie tylko samego ryzyka opcyjnego. Nawet na gruncie wykładni liberalnej niedopuszczalne wydaje się umieszczenie w ramowej umowie opcyjnej klauzul gwarantujących jednostronnie bankowi: (1) prawo do rozwiązana umowy, bez przyznania takiego uprawnienia klientowi, bądź (2) prawo odmowy zawarcia transakcji bez podania przyczyny, lub (3) prawo zamknięcia transakcji w przypadku naruszenia umowy przez klienta.

W końcu toksyczna asymetryczność rynkowa (funkcjonalna) wystappiłaby wtedy, gdyby międzynarodowe instytucje finansowe dostarczające polskim bankom opcji oferowanych następnie przedsiębiorstwom eksportowym (mówiąc precyzyjnie, podmioty międzynarodowe zawierały z polskimi bankami transakcje przeciwstawne, zabezpieczające otwarte pozycje walutowe polskich banków), poprzez zaangażowanie kapitałowe lub informacyjne (rekomendacje), grały w drugiej połowie 2008 r. na podwyższenie kursu EUR/PLN. Z prawnego punktu widzenia, jeśli jedna ze stron ma jednostronny wpływ na istotny składnik umowy ze szkodą dla drugiej strony - np. na cenę - i na dodatek wpływ ten przybiera postać kwalifikowaną, bo odbywa się poprzez nadużywanie pozycji dominującej (a więc z wyłączeniem zasady venire contra factum proprium nemini licet - chcącemu krzywda się nie dzieje), to mamy oczywistą (kwalifikowaną) bezprawność. Chodzi o sprzeczność jednocześnie z właściwością (naturą) stosunku zobowiązaniowego (który właśnie z natury jest dwustronny, a nie jednostronny) i z zasadami współżycia społecznego (zasada uczciwości). Taka sprzeczność, tak samo jak wszelka sprzeczność z naturą stosunku umownego skutkująca szkodą dla drugiej strony, oznacza toksyczność jako bezprawność. Tak byłoby np. gdyby właśnie na rynku opcji wystapili manipulatorzy, tj. podmioty nadużywające swojej pozycji w celu wywierania jednostronnego wpływu na ceny instrumentu pierwotnego. Byłaby to rynkowa toksyczność opcji walutowych. Racjonalnie rzecz ujmując, znaczenia prawnego nie miałaby tutaj okoliczność, że pozycji dominującej nadużywały nie banki będące stroną umów opcyjnych zawieranych z eksporterami, lecz międzynarodowe instytucje finansowe dostarczające polskim bankom opcji oferowanych następnie przedsiębiorstwom eksportowym (banki były per saldo jedynie pośrednikami).

Skoro przez toksyczne opcje walutowe rozumie się opcje (umowy opcyjne) sprzeczne z iuris cogentis, należy mówić o nieważności toksycznych opcji walutowych - art. 58 k.c. $\mathrm{z}$ zW. $\mathrm{z}$ art. 353-1 k.c.

\section{Zakończenie}

Toksyczne opcje walutowe zdefiniowano w tym opracowaniu w oparciu o opozycję wobec natury umowy opcyjnej, co znajduje uzasadnienie normatywne na gruncie klauzuli generalnej właściwość (natura) stosunku (będącej samoistną przesłanką reglamento- 
wania swobody zawierania umów). Tak rozumiane toksyczne opcje walutowe są bezprawne. Naruszają bowiem przepisy o charakterze iuris cogentis. Ich przykładem są:

1. Umowy opcyjne zawierane z bankiem w sytuacji, gdy bank przed zawarciem kontraktu nie poinformował klienta o ryzyku opcyjnym.

2. Opcje z barierą nastawioną jednostronnie na ochronę interesów banku.

Dlatego w grę wchodzi nieważność takich opcji. W takiej sytuacji wykonywanie umów na toksyczne opcje walutowe może być kwalifikowane jako karna niegospodarność menedżera. Z ostrożności menedżer powinien wtedy rozważyć wystąpienie z powództwem o ustalenie nieważności. Jednocześnie, jeśli członek rady nadzorczej danej spółki handlowej dopuszcza się zaniechania polegającego na niereagowaniu, np. nie składa zawiadomienia o podejrzeniu przestępstwa działania na szkodę spółki przez jej członków zarządu w sytuacji, gdy zarząd doprowadza do realizowania umów opcyjnych obarczonych nieważnością bezwzględną - to takie zachowanie członka rady nadzorczej może być kwalifikowane jako działanie na szkodę spółki.

Standard „dobrego gospodarza” jest traktowany przez najnowszą polską doktrynę i judykature jako ostateczne kryterium przy ustalaniu, czy kompetencje menedżera z norm karnoprawnych zostały wykonane. W 1951 r. orzecznictwo Sądu Najwyższego zastapienie „dobrego zarządcy”, „dobrym gospodarzem” objaśniało koniecznością odformalizowania kompetencji osoby gospodarującej. Odbywało się to ze względów ideologicznych, w ramach walki z ,przeżytkami burżuazyjnymi”. Dzisiaj - kierując się racjonalnością prakseologiczną, przedkładającą wiedzę teoretyczną nad praktyczną - należałoby uwzględnić stan wiedzy menedżerskiej in abstracto. Rzymskiemu standardowi diligentia boni patris familias (opartemu na arystotelesowskiej koncepcji człowieka doskonałego - Etyka nikomachejska, 1103a) należałoby nadać nowe objaśnienie: staranność dobrego menedżera. Na tak rozumianą zasadę dobrego menedżera składa się niewątpliwie elementarz z zakresu inżynierii finansów, obecnej w naszej cywilizacji od jej zarania, aczkolwiek masowo stosowanej dopiero współcześnie. Chodzi o pewne minimum minimorum wiedzy menedżerskiej, które wymyka się spod dyferencjacji powinności menedżerskich, co oznacza bezwzględny wymóg posiadania przez każdego menedżera pewnej minimalnej wiedzy z zakresu inżynierii finansów. Biorąc pod uwagę te postulaty, a także uwzględniając okoliczność, że przestępstwo działania na szkodę spółki nie jest przestępstwem skutkowym, tylko z narażenia - zauważymy, iż przy subsumcji istotny będzie komponent inżynierii finansów składający się na standard staranności dobrego menedżera. Oto na przykład, jeśli przy oczywistym trendzie spadkowym kursu euro menedżer nie kupi opcji put, może on podpadać pod zarzut działania na szkodę spółki (poprzez zaniechanie). Jak bowiem wynika $\mathrm{z}$ analizy ekonomicznej prawa, jeśli koszt uniknięcia ryzyka straty (B) był bardzo mały, a wielkość możliwych strat (L) duża, naruszenie zasady dobrego menedżera (co oznacza bezprawność karna) miało miejsce, choćby prawdopodobieństwo (P) straty było bardzo niewielkie. W przypadku wzrostu P można sobie pozwolić na zwiększenie B. Jednoczenie z analizy ekonomicznej prawa wynika, że jeśli B jest wyższy niż sama L, to też zostaje naruszona zasada dobrego menedżera. W takiej właśnie sytuacji prawnej znajdzie się menedżer, który zajmie krótką pozycję (na sprzedaż) na kontrakcie forward przy oczywistych trendach wzrostowych kursu euro. 
Natomiast co do zasady, menedżer eksportera nie powinien wystawiać jakiejkolwiek opcji. Wystawienie opcji zawsze oznacza branie na siebie zobowiązania. W przypadku walutowych opcji put jest to zobowiązanie do obligatoryjnego kupienia określonej kwoty euro po z góry określonym kursie, zaś wystawienie opcji call zobowiązuje do obligatoryjnego dostarczenia drugiej stronie kontraktu opcyjnego określonej kwoty euro po z góry określonym kursie. Ta druga pozycja (ang. short call) oznacza nieograniczoną stratę w przypadku aprecjacji euro. W tej sytuacji znaleźli się polscy eksporterzy w drugiej połowie 2008 r., którzy w połowie 2008 r. wystawiali bankom najbardziej ryzykowne opcje call, czyli kupowali od banków ryzyko walutowe. Wystawienie jakiekolwiek opcji oznacza więc zawsze kupowanie cudzego ryzyka, w zamian za stosunkowo niewielką premię opcyjną, co wiąże się z możliwością względnie dużego, wręcz nieograniczonego ryzyka strat, gdy zakładana prognoza się nie sprawdzi. Tutaj już nie chodzi o ekonomiczną analizę prawa odnośnie tego, czy koszt zapobieżenia ryzyka straty jest wyższy czy mniejszy niż szkoda. Menedżer przedsiębiorstwa eksportowego, w przeciwieństwie do spekulanta, który zajmuje się sprzedawaniem opcji (kupowaniem ryzyka), zwykle nie ma wiedzy z zakresu inżynierii finansów koniecznej do bezpiecznego zarządzania tym nadmiernym ryzykiem poprzez tworzenie portfela hedgingowego. Przy wystawieniu opcji dochodzi więc do narażenia na nadmierne ryzyko (działanie na szkodę spółki poprzez działanie sensu stricto).

W myśl obowiązującego prawa karnego, każdy odpowiada za swoje przestępstwo (w ramach następujących odmian: sprawstwo i współsprawstwo oraz podżeganie i pomocnictwo). Dlatego osoby nakłaniające eksporterów odnotowujących straty na opcjach do wykonywania umów opcyjnych, np. przy niewykonaniu przez banki obowiązku informacyjnego odnośnie ryzyka opcyjnego, albo w przypadku opcji z barierą nastawioną na jednostronną ochronę interesów banku, mogą podpadać pod zarzut podżegania lub pomocnictwa do karnej (zagrożonej karą) niegospodarności. W przypadku osób oddziaływujących na eksporterów poprzez banki w grę wchodzi podżeganie do podżegania lub pomocnictwo do pomocnictwa.

\section{Polish Toxic Currency Options}

\section{Summary}

Toxic currency options are defined on the basis of the opposition to the nature (essence) of an option contract, which is justified in terms of norms founded on the general law clause of characteristics (nature) of a relation (which represents an independent premise for imposing restrictions on the freedom of contracts). So-understood toxic currency options are unlawful. Indeed they contravene iuris cogentis regulations. These include for instance option contracts, which are concluded with a bank, if the bank has not informed about option risk before concluding the contract; or the barrier options, which focus only on the protection of bank's interests. Therefore, such options may appear to be invalid. Therefore, performing contracts for toxic currency options may be qualified 
as a criminal mismanagement. For the sake of security, the manager should then take into consideration filing a claim for stating invalidity (which can be made in a court verdict). At the same time, if the supervisory board member in a commercial company, who can also be a subject to mismanagement offences, commits an omission involving lack of reaction (for example, if he/she fails to notify of the suspected offence committed by the management board members acting to the company's detriment when the management board makes the company conclude option contracts which are charged with absolute invalidity) the supervisory board member so acting may be considered to act to the company's detriment.

In the most recent Polish jurisprudence and judicature the standard of a "good host" is treated to be the last resort for determining whether the manager's powers resulting from criminal regulations were performed. The manager of the exporter should not, as a rule, issue any options. Issuing options always means assuming an obligation. In the case of currency put options it is an absolute obligation to purchase a given amount in euro at exchange rate set in advance. On the other hand issuing call options confers an absolute obligation to deliver to the other party to the option contract a specified amount in euro at exchange rate set in advance. This latter position (short call) means unlimited loss in the case of appreciation of euro. This was the situation faced by some Polish exporters in the second half of 2008 who in the middle of 2008 issued the most risky call options for banks and, thus, they bought a currency risk from the banks. Issuing any option always means also buying someone other's risk, in exchange for a relatively small option premium which might trigger a relatively huge and actually unlimited risk of losses, if the assumed forecast does not come true. This is not the economic analysis of law to be relied on any more in respect of the cost of preventing the risk of loss being higher or lower than the amount of damage. The manager of an exporting company, unlike the speculator who sells options (buys risk), usually has no knowledge of financial engineering, which is essential to safely manage such excessive risk through creating a hedging portfolio. 